\title{
IMPLEMENTASI BIMBINGAN KARIR DALAM MENCAPAI PRESTASI KERJA KARYAWAN DI RESTORAN LOMBOK IDJO YOGYAKARTA
}

\author{
Husni Ismail \\ Prodi Interdisciplinary Islamic Studies, Bimbingan dan Konseling Islam \\ Pascasarjana UIN Sunan Kalijaga \\ (E-mail: husniismail19@gmail.com)
}

\begin{abstract}
Facing the challenge of globalization today, employees as human resources who have the ability, attitudes, values, needs, and characteristics must get great attention in an organization or company. Through guidance in the form of education and training can be viewed as one invesment, so that any organization or company that wants to grow and develop requires guidance for employees. This study aims to determine the implementation of career guidance in achieving employee performance in restaurants Lombok Idjo Yogyakarta. Understanding of career becomes important for employees in achieving targets and goals set by the company. By running the duties and responsibilities as employees will result in employee performance. Work is not just about getting money or economical course. But many things that make employees able to survive and continue to perform their duties as workers. Career concept and understanding is given by the management in the form of guidance in the form of individual and group. This research method uses qualitative research that describes the phenomenon that appears in the field. The data collection conducted by researchers are : observation, interviews, and documentation to obtain valid and accurate data. The results of this study indicate that there is a significant influence of career guidance on employee performance is given by the management. Achievement of position and promotion of office due to the achievement shown by employees through the attitude and good skills and duties and responsibilities carried out by employees during work in Lombok Idjo Yogyakarta.
\end{abstract}

Keyword : Career Guidance, Employee Performance

\section{Abstrak}

Menghadapi tantangan globalisasi saat ini, karyawan sebagai sumber daya manusia yang memiliki kemampuan, sikap, nilai, kebutuhan, dan karakteristikharus memperoleh perhatian yang besardalam sebuah organisasi atau perusahaan. Melalui bimbingan dalam bentuk pendidikan maupun pelatihan dapat dipandang sebagai salah satu investasi, sehingga setiap organisasi atau perusahaan yang ingin tumbuh dan berkembang memerlukan bimbingan bagi karyawan.Penelitian ini bertujuan untuk mengetahui implementasi bimbingan karir dalam mencapai prestasi kerja karyawan di restoran Lombok Idjo Yogyakarta.Pemahaman akan karir menjadi penting bagi karyawan dalam mencapai target dan tujuan yang sudah ditetapkan oleh perusahaan. Dengan menjalankan tugas dan tanggung jawabnya sebagai karyawan akan menghasilkan 
prestasi kerja karyawan. Bekerja bukan hanya sebatas memperoleh uang ataupun ekonomis saja. Tetapi banyak hal yang membuat karyawan mampu bertahan dan terus menjalankan tugasnya sebagai pekerja. Konsep dan pemahaman terhadap karir diberikan oleh pihak manajemen berupa bimbingan dalam bentuk individual dan kelompok. Metode penelitian ini menggunakan penelitian kualitatif yaitu mendeskripsikan fenomena yang muncul di lapangan. Adapun pengumpulan data yang dilakukan oleh peneliti yaitu: observasi, wawancara, dan dokumentasi untuk mendapatkan data yang valid dan akurat. Hasil penelitian ini menunjukkan bahwa ada pengaruh yang signifikan dari bimbingan karir terhadap prestasi kerja karyawan yang diberikan oleh pihak manajemen. Tercapainyaposisi dan promosi jabatan dikarenakan pencapaian prestasi yang ditunjukkan oleh karyawan melalui sikap dan keterampilan yang baik serta tugas dan tanggungjawab yang dilaksanakan oleh karyawan selama bekerja di Lombok Idjo Yogyakarta.

Kata kunci: Bimbingan Karir, Prestasi Kerja Karyawan

\section{A. Pendahuluan}

Setiap individu dilahirkan dengan sejumlah kebutuhan, tujuan, keinginan dan dorongan dasar. Dan untuk memenuhi itu semua, maka setiap individu harus bekerja.Abdul Hamid menjelaskan bahwa "pekerjaan manusia meliputi aspek rasio (akal) dan fisik. Jika manusia tidak bekerja maka hidup tanpa memenuhi tugasnya. Rasio manusia harus digunakan untuk berpikir, inilah yang membedakannya dari hewan dan tumbuhan. Salah satu kemampuan berpikir adalah kapabilitas menalar dan meneliti, menyimpulkan secara deduktif dan induktif. ${ }^{1}$ Dalam melaksanakan setiap aktifitas yang dilakukan, belum tentu memuaskan. Sehingga menjadiharapan bagi setiap orang adalah sukses atau berhasil, hal ini disebabkan kesuksesan atau keberhasilan seseorang dipengaruhi oleh beberapa faktor, baik internal maupun eksternal, khususnya dalam memahami arti kerjanya dan potensi dirinya.

Pemahaman arti kerja dan penelusuran karir atas dasar keinginan sendiri tidaklah mungkin muncul dengan sendirinya tanpa adanya bantuan dan dorongan dari seseorang yang profesional, kegiatan ini dinamakan dengan bimbingan. Pemberian layanan bimbingan khususnya masalah karir yang efektif dan memiliki kontinuitas akan bermanfaat bagi karyawan untuk memperoleh berbagai macam informasi karir, jabatan, pemahaman diri, pengambilan keputusan sendiri, dan

1 Abdul Hamid Mursi, SDM yang Produktif Pendekatan Al-Qur'an \& Sains, (Jakarta: Gema Insani Press, 1999), h. 34. 
memecahkan masalah itu sendiri. As'ad menyatakan bahwa kemampuan karyawan terhadap pemahaman kemampuan dan potensi diri tersebut merupakan indikasi keberhasilan layanan bimbingan dan konseling karir. Berhasil tidaknya layanan bimbingan karir tergantung pada kemampuan karyawan untuk mengambil keputusan tentang karir dan menanggung segala bentuk resiko yang dihadapinya kelak. Bimbingan karir tidak hanya sekedar memberikan respon kepada masalahmasalah yang muncul, akantetapi juga membantu memperoleh pengetahuan, sikap, dan keterampilan yang diperlukan dalam pekerjaan. Penggunaan istilah karir di dalamnya terkandung makna pekerjaan dan jabatan sekaligus rangkaian kegiatan dalam mencapai tujuan hidup seseorang. ${ }^{2}$

Hattari menyebutkan bahwa istilah bimbingan atau konseling karir mengandung konsep yang lebih luas. Seperti bimbingan jabatan menekankan pada keputusan yang menentukan pekerjaan tertentu, sedangkan bimbingan karir menitikberatkan pada perencanaan kehidupan seseorang dengan mempertimbangkan keadaan dirinya dengan lingkungannya agar ia memperoleh pandangan yang lebih luas tentang pengaruh dari segala peranan positif yang layak dilaksanakannya dalam masyarakat. ${ }^{3}$ Salah satu upaya untuk mencapai prestasi kerja karyawan yaitu dengan memberikan bimbingan karir. Salah satu hal yang membantu karyawan mengembangkan diri berkenaan dengan sikap dan kebiasaan bekerja yang baik untuk menguasai pengetahuan dan keterampilan adalah bimbingan atau konseling karir. Hanya saja untuk menghasilkan prestasi kerja yang tinggi seseorang karyawan tidak hanya perlu memiliki keterampilan, tetapi ia juga harus memiliki keinginan dan kegairahan untuk berprestasi tinggi. Hani Handoko menyatakan prestasi kerja sendiri merupakan ukuran keberhasilan atau kesuksesan seseorang karyawan itu sendiri dalam melaksanakan tugas atau pekerjaan selalu ingin mengetahui hasilnya baik atau buruk, dan adakemajuan atau kemunduran. ${ }^{4}$ Sementara Rao mengatakan bahwa prestasi suatu perusahaan

${ }^{2}$ Muh. As'ad, Psikologi Industri, (Yogyakarta: Lembaga Management Akademi Management Perusahaan YKPN, 1980), h. 42.

3 Hattari, Ke Arah Pengertian Bimbingan Karier dengan Pendekatan Developmental, (Jakarta: BP3K, 1983), h. 20.

4 Hani Handoko, Manajemen Personalia dan Sumber Daya Manusia, (Yogyakarta: BPFE, 2001), h. 75. 
tidak dapat dilepaskan dari prestasi kerja setiap individu yang terlibat didalamnya. ${ }^{5}$

Dalam suatu perusahaan agar pelaksanaan kerja dapat mencapai prestasi maka tidak hanya sekedar organisasi yang merupakan sekumpulan orang saja, melainkan melibatkan perlengkapan termasuk mesin-mesin, metode kerja dan penggunaan sumber tersebut benar-benar dapat berdaya guna. Dengan demikian perlu adanya pengaturan, pengarahan, bimbingan dan pendayagunaan. Usaha mengatur dan mengarahkan sumber daya ini, baik manusianya maupun peralatannya yang dikenal dengan istilah manajemen. Keefektifan organisasi perusahaan tercapai maupun tidak dapat terlihat apabila manajemen dapat memusatkan perhatiannya baik pada produksi maupun pada manusianya. ${ }^{6}$

Dalam hal ini, penulis ingin melihat bimbingan karir terhadap para karyawan di restoran Lombok Idjo Yogyakarta. Dimana bimbingan karir merupakan salah satu bagian dari manajemen, tanpa adanya bimbingan karir, maka kelangsungan hidup perusahaan tidak dapat berjalan secara efektif. Melalui bimbingan karir diharapkan tercapainya prestasi kerja karyawan, maka kualitas perusahaan dapat terwujud dengan baik. Begitu juga dalam manajemen rumah makan. Untuk memberikan pelayanan yang terbaik kepada tamu atau pelanggan, maka perlu adanya bimbingan karir bagi karyawannya, baik itu dengan pendidikan, pelatihan, pemberian motivasi, pemenuhan hak-hak karyawan dan sebagainya. Sehingga karyawan dapat memahami arti kerjanya dan pemahaman akan dirinya sehingga prestasi kerjanya tercapai yang akan menaikkan jenjang karirnya di perusahaan.

Seperti yang telah dilakukan oleh salah satu rumah makan di Yogyakarta yaitu Rumah Makan Lombok Idjo Yogyakarta, yang telah menerapkan bimbingan karirkepada para karyawannya. Hal ini dilakukan untuk mencapai prestasi kerja karyawan, sehingga baik pelayanan kepada tamu atau pelanggan menjadi lebih baik dan berkualitas maupun antar sesama karyawan.

${ }^{5}$ Rao, T.V, Penilaian Prestasi kerja: Teori dan Praktik (terjemahan: Mulyana), (Jakarta: Betnaman Pressindo, 1986), h. 56.

${ }_{6}^{6}$ Abdul Rahman Shaleh \& Yunita Faela Nisa, Psikologi Industri dan Organisasi, (Jakarta: UIN Jakarta Press, 2006), h. 4. 
Karena di Rumah Makan Lombok Idjo Yogyakarta memiliki jenjang karir yang akan diberikan bagi karyawan-karyawan yang memiliki prestasi kerja yang baik dan memuaskan. Posisi ataupun jabatan di Lombok Idjo sangat berhubungan erat dengan kemampuan yang dimiliki karyawan. Dengan bimbingan yang diberikan pihak manajemen sehingga menjadi harapan bagi karyawan yang ingin naik jabatan dan posisi yang lebih diunggulkan daripada sebelumnya.

Berdasarkan data di lapangan yang diteliti bahwa di Rumah Makan Lombok Idjo memiliki posisi/ jabatan yang beragam macam seperti mulai dari Divisi Diswasher, Server, Waiter, Bartender, Order Taker, Kitchen(Dapur), Kepala Divisi, Kepala Dapur, Asisten Dapur, Kapten, Supervisor, Asisten Manejer dan Manejer. Yang semuanya itu karyawan mempunyai hak yang sama dalam menduduki jabatan tersebut dengan prestasi yang ditunjukkan oleh karyawan. Dan pihak manajemen tidak tinggal diam bagaimana karyawan memperoleh jabatan tersebut yaitu dengan membimbing para karyawannya, artinya ada bimbingan karir yang diberikan oleh pihak manajemen terkait permasalahan kepribadian maupun teknik operasional.

\section{B. Metode Penelitian}

Metode yang digunakan dalam penelitian ini adalah deskriptif dengan pendekatan kualitatif. Metode deskriptif dapat diartikan sebagai prosedur pemecahan masalah yang diselidiki dengan menggambarkan suatu keadaan atau status fenomena dan melukiskan keadaan subjek/objek penelitian berdasarkan fakta-fakta yang tampak. Bersifat deskriptif dalam hal ini menggambarkan situasi tertentu atau data yang dikumpulkan berbentuk dalam kata-kata dan lebih memperhatikan proses daripada hasil atau produk semata. ${ }^{7}$ Melalui metode tersebut penulis mengumpulkan data selengkap mungkin tentang masalah yang diteliti. Dan kegiatan yang dilakukan penulis dalam penelitian ini adalah mengumpulkan data yang erat hubungannya dengan bimbingan karir dalam mencapai prestasi kerja karyawan berupa data ketika penelitian dilakukan.

7 Matthew B.M dan A.M Hubberman, Analisis Data Kualitatif, (Jakarta: UI PRESS, 1992), h.16. 


\section{Pembahasan}

\section{Konsep Bimbingan Karir}

Dalam pelayanan bimbingan dan konseling, secara umum penggunaan istilah karir tidak bisa lepas dari permasalahan saat ini. Hal ini perlu dikemukakan untuk memberikan wacana yang lebih luas dan fleksibel mengenai berbagai layanan serta bimbingan yang digunakan dalam pelaksanaan bimbingan dan konseling. Bimbingan dan konseling merupakan terjemahan dari "guidance"dan "counseling" dalam bahasa inggris. Secara harfiah (bahasa) istilah "guidance" dari akar kata "guide" berarti mengarahkan, memandu, mengelola, dan menyetir. ${ }^{8}$ Sedangkan konseling yang berarti menyerahkan atau menyampaikan. ${ }^{9}$ Menurut Frank Parson dalam Prayitno menjelaskan bahwa Bimbingan sebagai bantuan yang diberikan kepada individu untuk dapat memilih, mempersiapkan diri, dan memangku suatu jabatan yang dipilihnya. ${ }^{10}$ Lebih lanjut Prayitno menyimpulkan dari beberapa pakar konseling terhadap rumusan bimbingan, seperti diringkas Rumusan 1 Parson dalam Jones dalam rumusan di bawah ini:

a. Bimbingan diberikan kepada individu

b. Bimbingan mempersiapkan individu untuk memasuki suatu jabatan

c. Bimbingan menyiapkan individu agar mencapai kemajuan dalam jabatan Rumusan 2 Dunsmoor dan Miller dalam Mc Daniel

a. Bimbingan berusaha membantu individu

b. Bimbingan berusaha memahami dan menggunakan secara luas kesempatankesempatan yang tersedia yang meliputi kesempatan pendidikan, jabatan

c. Bimbingan dilakukan secara sistematik

d. Bimbingan bertujuan agar menyesuaikan diri dengan lingkungan sekolah dan kehidupan

Rumusan 3 Chiskolm dalam Mc Daniel

a. Bimbingan membantu setiap individu

b. Bimbingan berusaha agar klien memahami diri sendiri

8 Syamsu Yusuf, L.N dan A. Juntika Nurihsan, Landasan bimbingan dan konseling, (Bandung: PT. Remaja Rosda Karya, 2006), h. 5.

Prayitno dan Erman Amti, Dasar-Dasar Bimbingan dan Konseling (Jakarta: Rineka Cipta, 2013), h. 99.

${ }_{10}$ lbid, h. 93 . 
Rumusan 4 Lefever dalam Mc Daniel

a. Bimbingan merupakan bagian dari proses pendidikan

b. Bimbingan dilakukan secara teratur dan sistematik

c. Bimbingan diberikan kepada anak muda

d. Bimbingan menentukan dan mengarahkan dirinya sendiri

e. Bimbingan berusaha agar klien memperoleh pengalaman-pengalaman yang berguna

Rumusan 5 Smith dalam Mc Daniel

a. Bimbingan merupakan suatu proses layanan

b. Bimbingan memberikan bantuan kepada individu

c. Bimbingan bertujuan agar klien memperoleh pengetahuan dan keterampilan

d. Bantuan yang diberikan melalui bimbingan digunakan untuk membuat piilihan-pilihan, rencana-renana, dan interpretasi-interpretasi

e. Bentuan untuk penyesuaian diri yang baik

Rumusan 6 Crow dan crow

a. Bimbiingan merupakan bantuan yang diberikan sesorang laki-laki atau perempuan

b. Bimbingan berguna agar klien memiliki kepribadian yang memadai dan terlatih dengan baik

c. Bantuan melalui bimbingan diberikan kepada individu

d. Bimbingan untuk klien sembarang usia

e. Bimbingan bertujuan agar klien memperoleh kemandirian dalam membuat rencana dan keputusan-keputusan

f. Bimbingan bertujuan agar klien bertanggun jawab terhadap atas keputusankeputusan yang dibuat

Rumusan 7 Tiederman dalam Bernard dan Fullmer

a. Bimbingan membantu seseorang agar menjadi berguna

Rumusan 8 Mortensen dan Schmuller

a. Bimbingan merupakan bagian dari keseluruhan usaha pendidikan

b. Bimbingan menyediakan berbagai kesempatan

c. Bimbingan dilakukan oleh orang yang ahli

d. Bimbingan mengembangkan kemampuan secara opimal 
e. Bimbingan sesuai ide-ide demokratisasi bahwa masing-masing anak memiliki bakat, kemampuan, dan minat yang berbeda antara yang satu dengan yang lain

Rumusan 9 Bernard dan Fullmer

a. Bimbingan itu dilakukan dengan berbagai cara

b. Bimbingan dilakukan untuk meningkatkan perwujudan diri

c. Bimbingan diberikan kepada individu

Rumusan 10 Mathewson dalam Bernard dan Fulllmer

a. Bimbingan merupakan pendidikan dan perkembangan

b. Bimbingan ditekankan pada proses belajar

Rumusan 11 Jones dkk

a. Bimbingan merupakan proses bantuan

b. Bimbingan diberikan kepada individu

c. Bimbingan bertujuan agar klien dapat membuat pilihan-pilihan dan keputusan secara bijak

d. Bimbingan dilaksanakan berdasarkan atas prinsip-prinsip demokrasi bahwa setiap individu mempunyai hak dan kewajiban memilih jalan hidupnya sendiri

e. Dalam memilih jalan hidupunyaittu, individu tidak boleh mencampuri hak orang lain

f. Kemampua membuat pilihan-pilihandan keputusan-keputusan tidak diturunkan/diwarisi, melainkan harus dikembangkan sendiri oleh bersangkutan

Memperhatikan hal-hal pokok yang terkandung dalam setiap rumusan tentang bimbingan yang dikemukan di atas, tampak bahwa pelayanan bimbingan mengalami perkembangan yang cukup berarti dari masa kemasa, yaitu dari hanya sekedar mempersiapkan seseorang untuk memasuki suatu jabatan atau pekerjaan tertentu sampai dengan pemberian bantuan dalam pengentasan masalah-masalah di berbagai bidang, seperti masalah-masalah pendidikan, sosial, dan pribadi. Dengan demikian pelayaan bimbingan telah menjangkau berbagai aspek yang lebih luas dari perkembangan dan kehidupan manusia. Sehingga Prayitno menyimpulkan bahwa bimbingan adalah proses pemberian bantuan yang 
dilakukan oleh orang yang ahli kepada seorang atau beberapa individu, baik anakanak, remaja, dewasa. Agar orang yanng dibimbing dapat mengembangkan kemampuan dirinya sendiri dan mandiri, dengan memanfaatkan kekuatan individu dan sarana yang ada dan dapat dikembangkan bersasarkan norma-norma yang berlaku. ${ }^{11}$ Sedangkan secara terminologi, yang telah dikemukakan para ahli, seperti Rochman Natawijaya, bimbingan adalah suatu proses pemberian bantuan yang diberikan pada individu yang dilakukan secara berkesinambungan, supaya individu tersebut dapat memahami dirinya, sehingga dia sanggup mengarahkan dirinya dan dapat bertindak secara wajar, sesuai dengan tuntutan dan keadaan lingkungan sekolah, keluarga, masyarakat dan kehidupan pada umumnya. ${ }^{12}$

Secara umum dapat kita berikan batasan tentang bimbingan bahwa bimbingan adalah suatu proses tekhnis yang teratur, bertujuan untuk menolong individu dalam memilih penyelesaian yang cocok terhadap kesukaran yang dihadapinya. Dan membuat rencana untuk mencapai penyelesaian tersebut, serta menyesuaikan diri terhadap suasana baru yang membawa kepada penyelesaian itu. $^{13}$ Jadi bimbingan adalah bantuan yang diberikan kepada orang terbimbing, agar dapat memperkembangkan potensi yang dimiliki di dalam dirinya sendiri dalam mengatasi persoalan-persoalan, sehingga dapat menentukan sendiri jalan hidupnya secara langsung dan bertanggung jawab tanpa harus tergantung kepada orang lain.

Sedangkan karir jika merujuk pada Kamus Besar Bahasa Indonesia bahwa karir ialah perkembangan dan kemajuan dalam kehidupan pekerjaan. ${ }^{14}$ Sementara Moh. Surya, menyebutkan bahwa penyuluhan atau bimbingan karir merupakan teknik bimbingan karir melalui pendekatan individual dalam serangkaian wawancara penyuluhan (counseling interview)". ${ }^{15}$ Bimbingan ini merupakan pengkhususan kegiatan bimbingan atau konseling dalam masalah khusus yaitu masalah karir. Sementara menurut Donald Super bahwa bimbingan karir adalah

\footnotetext{
${ }^{11}$ Ibid, h. 99.

${ }^{12}$ Yusuf dan Nurihsan, Landasan Bimbingan dan Konseling, h. 6.

${ }^{13}$ Attia Mahmoud Hana, Bimbingan Pendidikan dan Pekerjaan I, (Jakarta: Bulan Bintang, 1978 ), h. 53.

14 Depdiknas, Kamus Besar Bahasa Indonesia, h. 508. 1994), h. 7.

15 Dewa Ketut Sukardi, Tes Dalam Konseling Karir, (Surabaya: Usaha Nasional,
} 
suatu proses perbantuan terhadap individu untuk menumbuhkan dan menerima gambaran tentang dirinya secara keseluruhan dan cocok baginya dalam lapangan pekerjaan, disamping menolongnya untuk mengalami gambaran tersebut dalam alam nyata dan mengubahnya kepada fakta nyata sedemikian rupa sehingga menjamin baginya kebahagiaan dan manfaat bagi masyarakat". ${ }^{16}$

Jadi, bimbingan karir adalah suatu proses bantuan dari pembimbing kepada klien dalam membantu klien mendapat gambaran tentang potensi dirinya, menetapkan jabatan pekerjaan, mengembangkan prestasi kerja ataupun pemecahan masalah yang dialami oleh karyawan dengan berbagai cara dan metode yang diberikan.

\section{Teori Karir John Holland}

Teori-teori kepribadian melihat preferensi pekerjaan sebagai ekspresi kepribadian. Mereka menyatakan kalau banyak perilaku pencarian karir merupakan sebuah pertumbuhan dari upaya-upaya untuk menyesuaikan karakteristik individu dengan bidang kerja tertentu. Pendekatan populer saat ini yang merepresentasikan teori kepribadian dalam bimbingan kerja adalah John Holland tentang tipe kepribadian dan model lingkungan. Teori ini didasarkan kepada asumsi utama tentang kepribadian dan determinasinya, dan kaitannya dengan beragam hasil dan pilihan kerja. Dengan kata lain, individu mengekspresikan dirinya sendiri, nilai yang dianutnya dan minat yang dikejarnya dan lain-lain melalui pilihan karir, sebuah lingkungan kerja bagi mereka. Konsep dan asumsi yang melandasi teori tersebut adalah :

a. Pilihan kerja merupakan ekspresi kepribadian.

b. Inventoti minat merupakan inventori kepribadian.

c. Streotip pekerjaan bisa digunakan dan makna-makna psikologis dan sosiologis sangat penting.

d. Anggota suatu pekerjaan memiliki kepribadian yang mirip dan sejarah perkembangan pribadi yang mirip.

e. Karena individu di kelompok kerja memiliki kepribadian yang serupa, mereka akan merespon banyak situasi dan problem dengan cara-cara yang h. 7 .

${ }^{16}$ Hana, Bimbingan Pendidikan dan Pekerjaan I, (Jakarta: Bulan Bintang, 1978), 
sama, dan bahwa mereka akan menciptakan lingkungan-lingkungan antarpribadi yang khas.

f. Kepuasan kerja, stabilitas dan prestasi bergantung pada kongruensi antara kepribadian dan lingkungan (dususun sebagia besar oleh orang lain) yang di mana seseorang bekerja. ${ }^{17}$

Teori ini seperti yang dieskripsikan oleh Hansen (2005), menyajikan sebuah kerangka kerja bagi perencanaan hidup secara interagtif. Label ini menggambarkan sebuah konsep pembaruan kembali dan membuat utuh dengan menyatukan bersama- sama pikiran, tubuh dan semangat individu. Pendekatan ini digambarkan sebagai kerangka holistik yang meluas untuk menyoroti perkembangan karir orang dewasa di tahap hidup yang berbeda-beda. Teori perencanaan hidup terintegrasi dalam model :

1) Mengaitkan konteks sosial dengan individu, keluarga, pendidikan atau pekerjaan.

2) Merupakan proses seumur hidup yang mengidentifikasikan kebutuhan, peran dan tujuan primer dan mengintegrasikannya di dalam diri, kerja, keluarga dan komunitas.

3) Sifatnya interagtif dan hubungan yang diorientasikan dan dirancang untuk membantu individu mencapai kepuasan, makna, kemenyeluruhan dan rasa komunitas yang lebih besar.

4) Merupakan suatu cara untuk membantu membentuk arah hidup seseorang, menguatkan orang lain, mengatur perubahan dan berkontribusi bagi masyarakat dan kebaikan yang lebih besar. ${ }^{18}$

Teori ini dikembangkan lebih jauh di sekitar 6 tema atau tugas kehidupan kritis yang mesti dihadapi orang dewasa di abad XXI. Hansen mendeskripsikan tugas-tugas tersebut sebagai berikut :

a) Menemukan kerja yang dapat memenuhi kebutuhan dalam sebuah konteks global yang terus berubah.

b) Menjadikan hidup bermakna secara menyeluruh.

c) Menghubungkan keluarga dan kerja.

17 Robert L. Gibson dan Marianne H. Mitchell, Bimbingan dan Konseling, (Yogyakarta: Pustaka Pelajar, 2011), h. 458.

${ }^{18} \mathrm{lbid}$, hlm. 465. 
d) Menghargai pluralisme dan keterbukaan.

e) Mengatur transisi pribadi dan perubahan organisasi.

f) Mengekplorasi spiritualitas dan tujuan hidup. ${ }^{19}$

\section{Tipe Kepribadian Holland}

Menurut John Holland ada beberapa tipe kepribadian yang menunjukkan pada cara dan karakteristik seseorang terhadap pekerjaan yang akan dijalankan. Tipe dan karakteristik tersebut dikelompokkan dalam tabel berikut :

\begin{tabular}{|c|c|}
\hline Tipe & Karakteristik \\
\hline $\begin{array}{l}\text { Realistik : Menyukai pekerjaan yang } \\
\text { realistik seperti mengutak-atik mesin } \\
\text { mobil, pesawat terbang, penyurvei, } \\
\text { petani, ahli listrik. Memiliki } \\
\text { kemampuan mekanik namun kadang } \\
\text { kurang memiliki keterampilan sosial. }\end{array}$ & $\begin{array}{l}\text { Asosial, menyesuaikan diri, terus terang, } \\
\text { apa adanya, keras, tidak fleksibel, } \\
\text { materialistik, alamiah, normal, gigih, } \\
\text { praktis, cukup-diri, hemat, tidak punya } \\
\text { ide, sulit mau terlibat. }\end{array}$ \\
\hline $\begin{array}{l}\text { Investigatif : menyukai pekerjaan } \\
\text { seperti biolog, ahli kimia, fisikawan, } \\
\text { antropolog, geolog dan tekhnolog } \\
\text { medis. Memiliki kemampuan } \\
\text { matematis dan ilmiah namun sering } \\
\text { kurang punya kemampuan } \\
\text { kepemimpinan. }\end{array}$ & $\begin{array}{l}\text { Analitis, berhati-hati, kompleks, kritis, } \\
\text { penuh ingin tahu, independen, } \\
\text { intelektual, introspektif, pesimis, tepat, } \\
\text { rasional, antisipatif, mengundurkan diri, } \\
\text { tidak berprasangka, tidak populer. }\end{array}$ \\
\hline $\begin{array}{l}\text { Artistik : menyukai pekerjaan seperti } \\
\text { komposer, musisi, sutradara, penulis, } \\
\text { dekorator, interior, artis. Memiliki } \\
\text { kemampuan artistik seperti menulis, } \\
\text { bermusik atau bentuk seni lainnya, } \\
\text { namun kurang punya kemampuan } \\
\text { administrasi yang baik. }\end{array}$ & $\begin{array}{l}\text { Rumit, tidak teratur, emosional, } \\
\text { ekspresif, adealistik, imajinatif, tidak } \\
\text { praktis, impulsif, independen, } \\
\text { introspektif, intuitif, tidak mudah } \\
\text { sepakat, terbuka, terbuka, orisinil, } \\
\text { sensitif. }\end{array}$ \\
\hline $\begin{array}{l}\text { Sosial : menyukai pekerjaan seperti } \\
\text { guru, pekerja rohani, konselor, }\end{array}$ & $\begin{array}{l}\text { Berpengaruh, kooperatif, empatik, } \\
\text { ramah, murah hati, siap menolong, }\end{array}$ \\
\hline
\end{tabular}

${ }^{19}$ Ibid, h. 465. 


\begin{tabular}{|c|c|}
\hline $\begin{array}{l}\text { pekerja sosial, psikiater/psikolog } \\
\text { klinis, terapis, dokter, perawat. } \\
\text { Memiliki keahlian dan talenta sosial } \\
\text { yang tinggi, namun sering kurang } \\
\text { punya kemampuan mekanik dan } \\
\text { ilmiah. }\end{array}$ & $\begin{array}{l}\text { idealistik, baik hati, sabar, persuasif, } \\
\text { bertanggung jawab, mudah bergaul, } \\
\text { bijak, penuh pengertian, hangat. }\end{array}$ \\
\hline $\begin{array}{l}\text { Pengusaha : menyukai pekerjaan } \\
\text { seperti sales, manajer, eksekutif } \\
\text { bisnis, prosedur tivi, promotor } \\
\text { olahraga, pialang saham, pekerja } \\
\text { iklan. Memiliki kemampuan } \\
\text { memimpin dan fasih berbicara namun } \\
\text { sering kurang punya kemampuan } \\
\text { ilmiah. }\end{array}$ & $\begin{array}{l}\text { Ambisius, berjiwa petualang, mudah } \\
\text { sepakat, tidak pernah rasa cukup, } \\
\text { mendominasi, penuh semangat, riang, } \\
\text { mencari, ekshibistionistik, ekstrover, } \\
\text { suka merayu, optimis, percaya diri, } \\
\text { mudah bergaul, enak diajak bicara. }\end{array}$ \\
\hline $\begin{array}{l}\text { Konvensional : menyukai pekerjaan } \\
\text { yang konvensional, seperti penjaga } \\
\text { toko, stenografer, pustakawan, } \\
\text { analisis finansial, bankir, pengesimasi } \\
\text { biaya, ahli pajak. Memiliki } \\
\text { kemampuan matematis dan aritmatis } \\
\text { namun sering kurang punya } \\
\text { kemampuan artistik. }\end{array}$ & $\begin{array}{l}\text { Cermat, menyesuaikan diri, penuh } \\
\text { kesadaran, defensif, efisien, tidak } \\
\text { fleksibel, pandai menahan diri, metodis, } \\
\text { patuh, teratur, gigih, praktis, sopan, } \\
\text { hemat, tidak imajinatif. }\end{array}$ \\
\hline
\end{tabular}

Sumber : John Holland, Self-Directed Search Professional (1985, 1987, 1994) Psychological Assesment Resources, Inc. ${ }^{20}$

\section{Tujuan dan Fungsi Bimbingan Karir}

Adapun tujuan dari bimbingan karir adalah untuk meningkatkan kontribusi sumber daya manusia (karyawan) terhadap organisasi dalam rangka mencapai produktivitas organisasi yang bersangkutan. ${ }^{21}$

${ }^{20} \mathrm{lbd}$, h. 464.

${ }^{21}$ Soekidjo Notoatmodjo, Pengembangan Sumber Daya Manusia, (Jakarta: PT. Rineka Cipta, 1998), h. 110. 
Hal ini dapat dipahami bahwa semua kegiatan organisasi dalam mencapai misi dan tujuannya adalah sangat tergantung kepada manusia yang mengelola organisasi itu. Oleh sebab itu sumber daya manusia (karyawan) tersebut harus dikelola sedemikian rupa sehingga berdaya guna dan berhasil guna dalam mencapai misi dan tujuaan organisasi. Adapun fungsi Bimbingan Karir adalah sebagai berikut:

a. Fungsi pengungkapan, fungsi ini merupakan suatu usaha untuk mengetahui adanya sesuatu keadaan dalam diri individu. Fungsi ini berusaha untuk memperoleh data tentang karyawan dan berdasarkan data itulah pembimbing dapat berbuat sesuatu sesuai dengan tingkat kesulitan masalah klien.

b. Fungsi pencegahan, fungsi ini berguna untuk memperkirakan hambatanhambatan yang mungkin timbul dari dalam diri karyawan. Dengan adanya fungsi ini maka dapat dicegah timbulnya hambatan-hambatan masalah sehingga dapat membantu perkembangan karyawan.

c. Fungsi penyaluran, fungsi ini merupakan usaha untuk membantu karyawan dalam hal memilih, menemukan sesuatu yang sesuai dengan apa yang ada pada diri karyawan.

d. Fungsi pengembangan, fungsi pengembangan merupakan kegiatan bimbingan yaitu membimbing karyawan dalam mengembangkan seluruh potensi yang dimilikinya, sehingga yang bersangkutan merasa puas dan bahagia dalam kehidupannya.

e. Fungsi Penyesuaian, fungsi ini merupakan usaha membantu karyawan untuk dapat menyesuaikan dirinya dengan lingkungannya dimana dia berada.

f. Fungsi pengarahan, fungsi ini merupakan usaha pembimbing untuk megetahui arah yang akan dituju oleh karyawan.

g. Fungsi informative, fungsi ini bertujuan untuk memberikan informasi kepada karyawan dapat memupuk seluruh potensi yang dimilikinya, sehingga karyawan dapat berkembang secara wajar.

h. Fungsi pemecahan, fungsi ini merupakan usaha untuk membantu kearah pemecahan masalah yang sedang dialami oleh karyawan. 
i. Fungsi perbaikan, fungsi ini bertujuan untuk memberikan usaha agar dalam diri karyawan timbul suatu perubahan. Dimana perubahan itu terbentuk perbaikan terhadap sautu yang kurang baik menjadi lebih baik. ${ }^{22}$

\section{Urgensi Bimbingan Karir Bagi Karyawan}

Bimbingan, baik berupa pendidikan maupun pelatihan dapat dipandang sebagai salah satu bentuk investasi. Oleh karena itu setiap organisasi atau instansi yang ingin berkembang, maka bimbingan bagi karyawannya harus memperoleh perhatian yang besar. Pentingnya bimbingan karir bagi karyawan antara lain, a) Sumber daya manusia atau karyawan yang menduduki suatu jabatan tertentu dalam organisasi, belum tentu mempunyai kemampuan yang sesuai dengan persyaratan yang diperlukan dalam jabatan tersebut. Hal ini terjadi karena sering seseorang menduduki jabatan tertentu bukan karena kemampuannya, melainkan karenatersedianya formasi. Oleh sebab itu karyawan atau staf baru ini perlu penambahan kemampuan yang mereka perlukan. b) Dengan adanya kemajuan ilmu dan teknologi, jelas akan mempengaruhi suatu organisasi/ instansi. Oleh sebab itu jabatan-jabatan yang dulu belum diperlukan, sekarang diperlukan. Kemampuan orang yang akan menempati jabatan tersebut kadang-kadang tidak ada. Dengan demikian, maka diperlukan penambahan atau peningkatan kemampuan yang diperlukan oleh jabatan tersebut. c) Promosi dalam suatu organisasi/ institusi adalah suatu keharusan, apabila organisasi itu mau berkembang. Pentingnya promosi bagi seseorang adalah sebagai salah satu reward dan insentive(ganjaran dan perangsang ). Adanya ganjaran dan perangsang yang berupa promosi dapat meningkatkan produktivitas atau prestasi kerja bagi seseorang karyawan. Kadang-kandang kemampuan seorang karyawan yang akan dipromosikan untuk menduduki jabatan tertentu ini masih belum cukup. Untuk itulah maka diperlukan bimbingan karir baik berupa pendidikan maupun latihan tambahan. d) Di dalam masa pembangunan ini organisasi-organisasi atau instansiinstansi, baik pemerintah maupun swasta merasa terpanggil untuk menyelenggarakan pelatihan-pelatihan bagi karyawannya agar diperoleh efektivitas dan efiisensi kerja sesuai dengan masa pembangunan. ${ }^{23}$

\footnotetext{
${ }^{22}$ Slameto, Bimbingan di Sekolah, (Jakarta : Bina Aksara, 1988), h. 12-16.

${ }^{23}$ Notoatmodjo, Pengembangan Sumber Daya Manusia, h. 27-28.
} 
Pentingnya bimbingan karir seperti diuraikan di atas bukanlah sematamata bagi karyawannya atau pegawai yang bersangkutan, tetapi juga keuntungan bagi organisasi. Karena dengan meningkatnya kemampuan atau keterampilan para karyawan maka akan meningkat pula produktivitas kerja para karyawan. Produktivitas kerja karyawan meningkat, berarti organisasi yang bersangkutan akan memperoleh keuntungan.

\section{Prestasi Kerja Karyawan}

Prestasi kerja disebut juga sebagai "kinerja" atau dalam bahasa Inggris disebut dengan "performance". Pada prinsipnya, ada istilah lain yang lebih menggambarkan pada "prestasi" dalam bahasa Inggris yaitu kata "achievement".Tetapi karena kata tersebut berasal dari kata "to achieve"yang berarti "mencapai", maka dalam bahasa Indonesia sering diartikan menjadi "pencapaian" atau "apa yang dicapai". ${ }^{24}$ Bernardin dan Russel memberikan pengertian tentang prestasi kerja sebagai“performance is defined as the recordof outcome produced on a specified job function or activity during a specified time period". ${ }^{25}$ Dengan artian bahwa prestasi kerja didefinisikan sebagai catatan dari hasil-hasil yang diperoleh melalui fungsi-fungsi pekerjaan tertentu atau kegiatan selama tempo waktu tertentu. Sehingga prestasi kerja lebih menekankan pada hasil atau yang diperoleh dari sebuah pekerjaan sebagai konstribusi pada perusahaan. Tingkat tinggi rendahnya hasil kerja yang dihasilkan oleh karyawan dalam pekerjaannya sering dinamakan prestasi kerja.

Secara lebih jelas sperti yang dikemukakan oleh Hani Handoko yang dimaksud dengan prestasi kerja adalah hasil kerja yang dicapai oleh tenaga kerja atau karyawan dalam melaksanakan tugas dan pekerjaan yang dibebankan kepadanya. $^{26}$

${ }^{24}$ Ahmad S.Ruky, Sistem Manajemen Kinerja, (Jakarta: PT.Gramedia Pustaka Utama, 2006), h. 15.

25 lbid, h. 16.

26 Hani Handoko, Manajemen Personalia dan Sumber Daya Manusia, (Yogyakarta: BPFE, 2001), hlm. 75. 


\section{Pembahasan}

Penelitian ini dilakukan di Rumah Makan Lombok Idjo Yogyakarta tepatnya di Jl. Laksda Adi Sucipto No.22 kota Yogyakarta. Rumah Makan yang posisi nya di pusat keramaian ini sehingga banyak dikunjungi oleh berbagai kalangan, mulai dari pelajar yang memang dekat dengan kampus UIN Sunan Kalijaga, juga para pekerja-pekerja yang dekat dengan Rumah Makan. Bahkan tidak terlepas juga artis-artis ternama Indonesia seperti Agnes Monica, Dimaz Andrean, Midun yang pernah mengunjungi restoran ini, sampai pejabat Negara seperti Menteri Pertanian yang sudah menginjakkan kakinya dan merasakan nikmatnya santapan dan pelayanan karyawan di Rumah Makan ini. Tetapi semua ini tidak terlepas dari keorganisasian yang ada di Rumah Makan ini. Artinya jika melihat dari hasil wawancara dengan pihak manajemen bahwa memang selain dari segi kualitas dan rasa makanan yang dihidangkan juga pelayanan dan kesan para karyawan yang membuat pelanggan lebih senang dan nyaman, sehingga banyak yang menjadi pelanggan setia Rumah Makan ini.

Karyawan tidak begitu mampu dan memberikan pelayanan yang terbaik kepada pelanggan jika tidak dibimbing dan diarahkan sesuai potensi yang dimiliki oleh para karyawan. Pemberian bimbingan khususnya tentang potensi diri dan kepribadian yang baik yang menjadikan karyawan yang sebelumnya tidak mengerti apa-apa menjadi lebih mandiri dan unggul di bidangnya, bahkan banyak diantara karyawan yang memang tidak berpendidikan tinggi hanya sebatas Sekolah Dasar dan SMP. Tetapi dengan bimbingan yang diberikan potensi-potensi yang dimiliki oleh karyawan mulai tergali dan muncul sebagai pribadi yang punya tanggung jawab dan kedisiplinan yang tinggi khususnya di bidang karir dan jabatan yang diemban.

Bimbingan Karir diberikan oleh pihak manajemen disetiap akhir bulan,seperti bimbingan diberikan oleh Manejer, asisten Manejer dan juga Supervisor yang bertanggung jawab sepenuhnya terhadap kemampuankemampuan dan kecakapan para karyawan melalui pelatihan-pelatihan seperti bimbingan dan praktik, baik dalam bentuk individual maupun kelompok. Seperti pemberian pemahaman arti kerja dan potensi diri, pemberian motivasi, pemahaman sikap dan keterampilan, tugas dan tanggung jawab. Semuanya 
dirumuskan dan direncanakan oleh pihak manajemen sehingga karyawan mampu mengenal potensi dirinya dan mampu mengambil keputusan yang baik dan bahkan memecahkan permasalahan yang muncul di Rumah Makan Lombok Idjo.

Di Rumah Makan Lombok Idjo memiliki beberapa jabatan/ posisi yang setiap karyawan berhak menempatinya, dengan syarat memilki prestasi kerja serta kualifikasi dan kemampuan yang lebih dibandingkan karyawan yang lain. Banyak diantara karyawan yang sebelumnya memiliki posisi dibawah yang diangkat menjadi lebih diatasnya dengan prestasi kerja yang ditunjukkan oleh karyawan. Seperti contohnya, Bapak Wahyu Setyo yang sebelumnya posisi waiter dan server sekarang menduduki jabatan Supervisor, Bapak Reza yang sebelumnya cleaning service sekarang Asisten Kepala Dapur, Ibu Windu yang sebelumnya posisi Waiter sekarang jabatan Kapten. Artinya dengan prestasi yang ditunjukkan oleh karyawan pihak manajemen tidak menutup mata akan menaikkan posisinya, yang dalam bahasanya Lombok Idjo Promosi Jabatan bagi karyawan yang memilki kualitas dan keterampilan yang baik.

\section{E. Kesimpulan}

Penulis menyimpulkan bahwa ada pengaruh besar dan signifikan dari bimbingan karir terhadap kinerja dan prestasi para karyawan yang diberikan oleh pihak manajemen melalui bimbingan baik kelompok maupun individual. Naiknya jabatan/ posisi karyawan yang sebelumnya posisi dibawah dikarenakan pencapaian prestasi yang ditunjukkan para karyawan melalui kepribadian serta tugas dan tanggung jawab yang diperlihatkan dan diemban oleh karyawan selama di Lombok Idjo. Sehingga keorganisasian di Lombok Idjo akan terus semakin kuat dan semakin erat jika terus dibimbing dan diarahkan sesuai bidang dan posisi masing-masing divisi. 


\section{Daftar Pustaka}

Ahmad S.Ruky, 2006, Sistem Manajemen Kinerja, Jakarta : PT.Gramedia Pustaka Utama.

Abdul Hamid Mursi, 1999, SDM yang Produktif Pendekatan Al-Qur'an \& Sains, Jakarta: Gema Insani Press.

Abdul Rahman Shaleh \& Yunita Faela Nisa, 2006, Psikologi Industri dan Organisasi, Jakarta: UIN Jakarta Press.

Attia Mahmoud Hana, 1978, Bimbingan Pendidikan dan Pekerjaan I, Jakarta: Bulan Bintang.

Depdiknas, Kamus Besar Bahasa Indonesia

Dewa Ketut Sukardi, 1994, Tes Dalam Konseling Karir, Surabaya: Usaha Nasional.

Hattari, 1983, Ke Arah Pengertian Bimbingan Karier dengan Pendekatan Developmental, Jakarta: BP3K.

Hani Handoko, 2001, Manajemen Personalia dan Sumber Daya Manusia, Yogyakarta: BPFE.

Hana, 1978, Bimbingan Pendidikan dan Pekerjaan I, Jakarta: Bulan Bintang.

Hani Handoko, 2001, Manajemen Personalia dan Sumber Daya Manusia, Yogyakarta: BPFE.

Muh. As'ad, 1980, Psikologi Industri, Yogyakarta: Lembaga Management Akademi Management Perusahaan YKPN.

Matthew B.M dan A.M Hubberman, 1992, Analisis Data Kualitatif, Jakarta: UI Press.

Robert L. Gibson dan Marianne H. Mitchell, 2011, Bimbingan dan Konseling, Yogyakarta: Pustaka Pelajar

Rao, T.V, 1986, Penilaian Prestasi Kerja: Teori dan Praktik (terjemahan : Mulyana), Jakarta: Betnaman Pressindo.

Syamsu Yusuf, L.N dan A. Juntika Nurihsan, 2006, Landasan Bimbingan dan Konseling, Bandung: PT. Remaja Rosda Karya.

Soekidjo Notoatmodjo, 1998, Pengembangan Sumber Daya Manusia, Jakarta : PT. Rineka Cipta.

Slameto, 1988, Bimbingan di Sekolah, Jakarta : Bina Aksara. 